http://dx.doi.org/10.18778/7969-268-2.11

Tomasz Kamiński

\title{
THE IMPACT OF THE CURRENT ECONOMIC CRISIS ON THE CHINESE POSITION IN EUROPE
}

It is commonly believed that the economic crisis has changed the balance of power in the world. We can observe the relative deterioration of Europe's international position vis-a-vis large players, including the United States, China and Russia. Losses may be seen in every area, whether it be ideological, political, economic or military. The EU, forced to ask for investment assistance for instance in China, has lost a lot of its prestige. The might of the United States is also in relative decline. In economic and political terms this country lost much of its former status of unrivalled superpower. China is perceived as one of the countries that benefits the most from global disorder. We can already notice a growing Chinese economic presence in Europe, and while some accept it with hope, others worry. Many experts have expressed their anxiety about the rising political influence of China, and ordinary people from EU member states claim that they are afraid of China. The main aim of this paper is to confront the hopes and worries with facts, and to answer the following questions:

1. Do the Chinese economic activities in Europe during this turbulent time of crisis pose a real danger for the EU?

2. To what extent has China gained a better political position in Europe and should we be afraid of a so-called "Chinese lobby" in the Council?

3. Could China really be an important part of the solution to the economic crisis in Europe?

Chinese activities in Europe will be presented in the theoretical framework of neorealism/defensive realism, which seems to be especially useful for the purpose of this paper due to the fact that it is the dominant school of thought in China. Neorealists may be sub-divided into 'offensive' and 'defensive' camps, with the latter being particularly influential. Although both are focused on securing national interests, defensive realists do not seek security by intentionally decreasing the security of others, and do not believe that conflicts of interests 
are irreconcilable. ${ }^{1}$ Conflicts of interests between actors do matter, but cooperation is a possible option for their resolution. ${ }^{2}$ Tang persuasively proves that China's strategy is deeply rooted in defensive realism, which means that Beijing will be focused on national interests, and rather reluctant to seek coercive ways of resolving conflicts with other actors. ${ }^{3}$

As far as the definition of power is concerned, the Whalley concept of economic power is particularly useful. This notion of power puts an emphasis on market size (including retaliatory power), bargaining power in cooperative arrangements between countries, and that power which stems from legitimacy (or intellectual power). ${ }^{4}$

\section{Growing economic power}

The economic crisis that began in 2008 affected all major players on the world stage. It has accelerated shifts in the global distribution of power to such an extent that it has changed the global balance of power. ${ }^{5}$ The People's Republic of China (PRC) has in all probability benefited the most from the economic turbulence and global disorder. Although China has also suffered from the economic crisis, its government has managed rather efficiently to cushion the negative impact of the global slowdown. ${ }^{6}$ The slump in demand for Chinese products in the US and Europe, which are the two most important markets for China, affected its economic growth and exposed the structural problems in its economy, such as growing unemployment or even deeper regional disparities. The underdeveloped financial sector, ${ }^{7}$ although not that much exposed to international turbulence, was not able to quickly revive a slumping economy. For the ruling Chinese Communist Party (CCP), the exponential wealth of Chinese society is the major legitimization of its power and the government

${ }^{1}$ S. Tang, From Offensive to Defensive Realism: A Social Evolutionary Interpretation of China's Security Strategy, [in:] China's Ascent. Power, Security, and the Future of International Politics, eds. R. Ross, F. Zhu, Cornell University Press, Ithaca, NY 2008.

2 Ch. Glasser, Realists as Optimists: Cooperation as Self-Help, "International Security" 1994, no. 19 , p. 50-90.

${ }^{3}$ S. Tang, From Offensive to Defensive Realism: A Social Evolutionary Interpretation of China's Security Strategy, State of Security and International Studies, Rajaratnam School of International Studies, Singapore 2007.

4 J. Whalley, Shifting Economic Power, OECD September 2009, http://www.oecd.org/dev/ pgd/45337859.pdf, p. 43 [access: 29.09.2014].

${ }^{5}$ Z. Brzezinski, Strategic Vision: America and the Crisis of Global Power, Basic Books, New York 2012.

${ }^{6}$ Y. Zheng, S.Y. Tong (eds.), China and the Global Crisis, World Scientific 2010; G. Chance, China and the Credit Crisis. The Emergence of the World Order, Wiley, New York 2010.

${ }^{7}$ C. Walter, F.J.T. Howie, Red Capitalism. The Fragile Foundation of China's Extraordinary Rise, Wiley, New York 2011. 
reacted forcefully at the first signs of economic slowdown. A stimulus package, as large as almost 586 billion USD (4 billion RMB), was perceived as a great success. It reinvigorated bank loans, and in the first quarter of 2009 banks lent the equivalent of $10 \%$ of GDP. ${ }^{8}$ This resulted in a quick return to double-digit GDP growth, of $10.4 \%$ in 2010 , incomparably greater than that of any other large economy in the world.

The Chinese economic success during the time of crisis led to a shift in the economic power in the world. From 2008 to 2012 the GDP of China, counted in USD, almost doubled (from 4,551,827 million to 8,226,885 million USD (according to the National Statistical Bureau of China), improving its relative position versus the EU and the United States. While the Chinese economy, in terms of GDP, is still only half as big as the economies of America or Europe; nonetheless the relative change is still impressive. That raises the question: to what extent does such a shift in economic power influence relations with partners and the political position of China?

\section{Facts and Fears}

The growing Chinese economic presence in Europe has already been noticed. Many experts and journalists have expressed their anxiety regarding the rising political influence of China and its growing potential to exploit and exacerbate European disunity. The vision of European nations competing with each other to attract Chinese investment with all sorts of incentives is threatening for the EU. ${ }^{9}$ Ordinary people are afraid of Chinese economy. In 2011 so many as $41 \%$ of citizens from twelve EU member states claim that they are afraid of China while only $46 \%$ see it as an opportunity. ${ }^{10}$

The most wide-spread fears can be summarized as follows:

- Rising Chinese competition costs Europe billions in lost jobs. However consumers are the winners who enjoy cheaper products, the losers are the displaced workers whose incomes suffer and the taxpayers who must support them.

- The crisis paved the way for a more protectionist EU trade policy that will lead to trade wars with China. During economic turbulences the EU's accusation of Chinese companies benefiting from unfair state aid allowing them to dump goods in Europe, receive general recognition.

${ }^{8}$ B. Naughton, China Response to the Global Crisis and Lessons Learned, [in:] The Global Recession and China's Political Economy, eds. D.L. Yang, Palgrave/Macmillan, Basingstoke 2012, p. $15-32$.

9 Eg. S. Meunier, China as Savior or Predator in Europe?, 2011, http://www.huffingtonpost. com/sophie-meunier/china-as-savior-or-predat_b_1074282.html [access: 29.09.2014]; F. Godement, J. Parello-Plesner, Wyścig po Europę, Fundacja im. Stefana Batorego, Warszawa 2011.

${ }_{10}$ Transatlantic Trends. Key Findings 2011, http://www.gmfus.org/publications_/TT/TT2011_ final_web.pdf [access: 29.09.2014]. 
- China is going to buy up strategic European assets, most of all in the energy and infrastructure sectors, that are perceived as "politically sensitive".

- China can exploit the vulnerability of some European countries by offering financial aid in exchange for political support. That may result in the creation of a so-called "Chinese lobby" of smaller member states within the EU.

Do the economic activities of China in Europe during this turbulent time of crisis pose a real danger for the EU?

\section{Does China steal or create jobs?}

Since the start of the economic and financial crisis in 2008 , the number of jobs lost in the EU has reached 5 million, of which 4 million were lost in the euro area. ${ }^{11}$ It is hard to measure the impact that China has had on these numbers. On one hand, undoubtedly harsh competition from China influences some sectors of the European economy. On the other hand, some experts argue that rising competition from China is in fact beneficial to the EU economy. ${ }^{12}$ They argue that the effect of reduced employment is significant only for the low-tech sectors, and that Chinese import competition has "led to increased technical change within firms and reallocated employment between firms towards more technologically advanced firms. These within and between effects were about equal in magnitude, and appear to account for 15\% of European technology upgrading over 2000-2007."13

The positive impact of China on the European labour market in times of crisis is visible in some sectors. One of them is the tourism industry. The number of Chinese tourists arriving in Europe totalled 5.7 million in 2012. ${ }^{14}$ This is a small fraction of the tourism market when compared to the number of American tourists (82 million in 2012), but still the growth trend is impressive. Until 1994 Chinese citizens were not permitted to leave the Asian continent for leisure, and until 2001 were only allowed to travel as part of organized tours. The recent inflow of Chinese tourists represents a radical change and opens new economic benefits for European companies.

For the European luxury branches of business, Chinese clients have become one of the most important groups. In some exclusive shops in London or Paris (the most popular European destination for rich Chinese tourists), they account for 50\% of foreign visitors, and are responsible for $30 \%$ of the total turnover. According

${ }^{11}$ Council of European Union, Joint Employment Report, 4 March 2013, No. 6799/13.

${ }_{12}$ N. Bloom, M. Draca, J. van Reenen, Trade Induced Technical Change? The Impact of Chinese Imports on Innovation, IT and Productivity, CEP Discussion Paper 2011, No. 1000.

${ }_{13}$ This research was based on data covering the years before the crisis, there is no direct evidence that such a phenomenon is still visible today.

${ }^{14}$ European Travel Commission, European Tourism in 2013: Trends \& Prospects. Quarterly Report 1/2013, Brussels May 2013, http://www.etc-corporate.org/reports/tourism-trends 
to British estimates, Chinese visitors spend on average $£ 1,618$ on a trip to Britain, which is three times more than the average spent by other international tourists. ${ }^{15}$

Chinese citizens travel to Europe not only for shopping, but also for medical procedures, attracted by the top-level technology and standards of care. Even though eight thousand patients a year is still a relatively small number, it represents a $30 \%$ increase every year, and an average expenditure for each of those trips estimated to be $€ 100,000$, it demonstrates a significant potential for growth for the medical sector. ${ }^{16}$

The large, fast growing economy of China, apart from "stealing European jobs", also creates new opportunities in some sectors. Chinese demand has gained importance during the crisis, although its impact on European markets should not be overestimated, at least with respect to the short term.

\section{No trade war with China}

European trade with China was not affected that much by the financial crisis, at least from the point of view of Brussels. The EU's exports to China have been growing steadily and the import crash noted in 2009 led to the first decrease of the trade deficit with China since it entered the WTO in 2001. Similarly to relations with other big partners (USA, Russia), in 2010 trade came back on the growing track.

The European trade deficit with China, a source of major political battles before the crisis, still remains relatively large, but it is not a burning issue any more. It is decreasing in absolute as well as in relative terms. In 2008 the deficit was equal to more than half of the EU-China trade. By comparison, in 2012 it was only one third.

The crisis has eased the most important economic problem in bilateral relations: the deep trade imbalance in favour of China. However, the situation with respect to access to the Chinese market is far from being acceptable for the EU. Since the financial crisis, European political pressure on China has become even stronger, as trade barriers have become more bothersome for European companies struggling with reduced demand. In June 2012, the EU Ambassador to the WTO, Angelos Pangratis, presented a long list of accusations and demands, stressing that China is not fulfilling its obligations. ${ }^{17}$ In truth however, there was nothing new in the list; a similar one was published by the European Commission

${ }^{15}$ H. Warrell, G. Parker, H. Kuchler, Plea to ease UK visas for Chinese tourists, "Financial Times", October 5, 2012.

${ }^{16}$ Delegation of the European Union to China, Europe Attracts The Changing Face of Chinese Tourism, http://newsletter.eu-in-china.com/newsletters/201208/business1_en.html

17 A. Pangratis, Statement by EU Ambassador to the World Trade Organisation, "Fourth Trade Policy Review of China", 12 and 14 June 2012, http://trade.ec.europa.eu/doclib/docs/2012/june/ tradoc_149542.pdf. 
in 2006. ${ }^{18}$ It is worth noting that during the crisis China has not imposed any new protectionist measures, although they have preserved the rather slow pace of abolishing old ones.

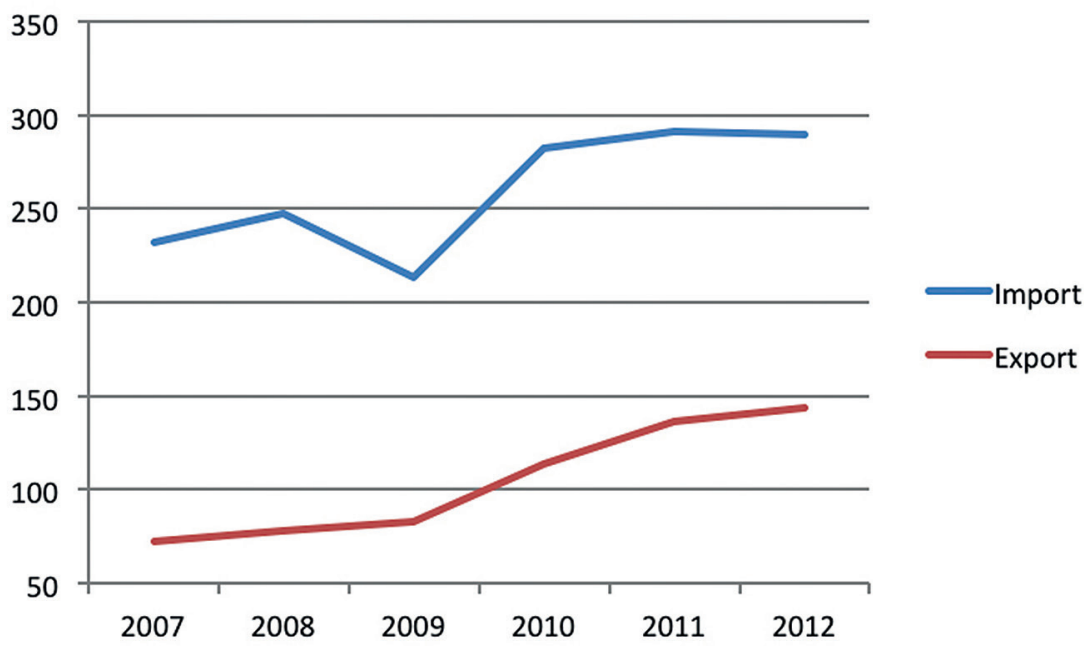

Graph 1. European export and import to China in years 2007-2012 (in billions EUR) Source: Eurostat

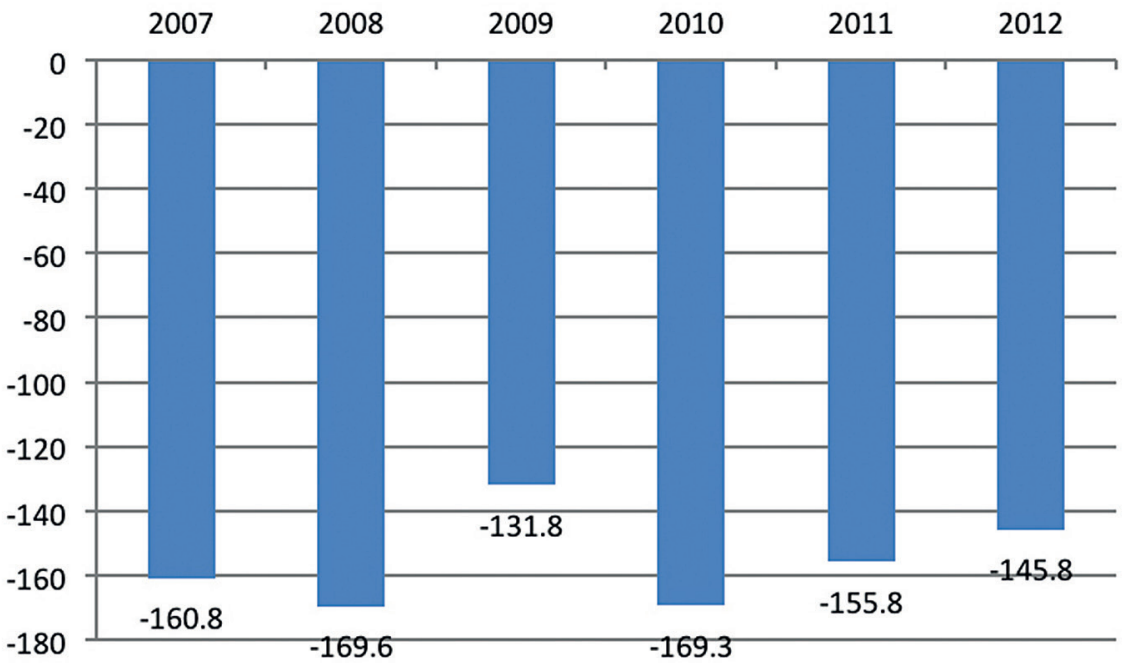

Graph 2. The EU trade balance with China in the years 2007-12 (in billions of EUR) Source: Eurostat

${ }^{18}$ European Commission, Competition and Partnership. A Policy paper on EU-China trade and investment, Brussels, 24.10.2006, COM (2006) 632. 
During the turbulent times of economic slowdown many experts were afraid of repeating the "Great Depression" scenario, when the crisis led to an outbreak of protectionism. But these fears have not come true. Many new political initiatives have demonstrated the opposite - free trade is perceived as a solution rather than a source of problems.

\section{Are they buying us up?}

Chinese investments in Europe have become a hot issue in recent years and have attracted a lot of analysts' attention. ${ }^{19}$ Starting from about 700 million USD annually (2004-2008), Chinese investments in Europe tripled in 2010 and reached 12.6 billion USD in 2012. On one hand China is using the crisis to snap up bargains, but on the other hand its investment activities are a natural consequence of its companies developing and internationalizing.

Although growing rapidly, Chinese investments are still less than $5 \%$ of EU foreign direct investment (FDI) inflow. ${ }^{20}$ The biggest stake was invested in three countries: Germany, France and Great Britain, although Hungary ( $5^{\text {th }}$ place) and Greece $\left(8^{\text {th }}\right)$ have also attracted a lot of Chinese money. ${ }^{21}$ However, even in a small state such as Hungary the total Chinese investment in the last ten years is a mere $3 \%$ of all FDI in the country, which is estimated to be 65 billion EUR. ${ }^{22}$

Even more importantly, there is no evident correlation between Chinese investments and the policy of a particular European state in relation to human rights or embargo on weapons. It may be concluded that Chinese business activities in Europe so far are driven mainly by commercial and not political motives. Maybe this is due to the fact that $2 / 3$ of investors are private companies. ${ }^{23}$

The profile of a Chinese investor in Europe is completely different to one investing in Africa, where the main role is played by state-owned enterprises, which realize the political goals of their owner. ${ }^{24}$ Furthermore, in Africa the Chinese are concentrated on the mining sector and raw materials, while in Europe their investments are diversified between many sectors.

${ }_{19}$ T. Hanemann, D. Rosen, China Invests in Europe. Patterns, Impacts and Policy Implications, Rhodium Group 2012; J. Clegg, H. Voss, Chinese Overseas Direct Investment In The European Union, Europe China Research and Advice Network 2012.

20 T. Hanemann, D. Rosen, China Invests in Europe...

${ }^{21}$ F. Hay, Ch. Milelli, Y.Shi, The Impact of the Global Financial Crisis on the Presence of Chinese and Indian Firms in Europe, Sussex Academic Press, Eastbourne 2012.

${ }^{22}$ Hungarian Investment and Trade Agency, http://www.hita.hu/en/Content.aspx?ContentID=220482e5-5231-4d5f-bf8a-bbe11268d14a. [access: 01.06.2013].

${ }^{23}$ T. Hanemann, D. Rosen, China Invests in Europe..., p. 4.

${ }^{24}$ A. Amighini, R.Rabellotti, M. Sanfilippo, Do Chinese SOEs and Private Companies Differ in Their Foreign Location Strategies?, EUI Working Papers, RSCAS 2012, Vol. 27. 
Beijing owns more than 3 trillion USD in foreign currency reserves and is an important player on the bond market. However, nobody knows how much China has invested in EU bonds (there is no official data published by either China or the EU), though one can estimate that their engagement is far too low to be crucial. Even if we optimistically assumed that $25 \%$ of their reserves is denominated in euro, this amounts to 650 billion EUR, which is less than $10 \%$ of the whole eurozone public debt.

During the darkest hour of the financial crisis in the EU, China was perceived as a potential lifesaver for some indebted eurozone states. For instance, in January 2011 Deputy Prime Minister Li Keqiang was cordially welcomed by Spaniards, who were counting on Chinese generosity in buying bonds. Chinese diplomats promised to spend 6 billion EUR on them. ${ }^{25}$ Even if this were to occur, it would be rather a friendly gesture than a real solution to Spain's problems. The aforementioned sum equals just $1 \%$ of Spanish public debt and amounts to only 5\% of the international financial support for Greece. The money promised by China was only a fraction of the real needs at that time.

China was obviously interested in evading a disastrous breakdown in the eurozone. However, it is quite incredulous to think that the Chinese, who manage their reserves rather cautiously, would decide to invest heavily in the risky assets of some European countries on the verge of bankruptcy. It should be noted that the Chinese sovereign wealth fund, China Investment Corporation, declared in 2012 that they had stopped buying European bonds. ${ }^{26}$ As Jacob Funk Kirkegaard noted "appropriately for a very wealthy region, the EU has relied on its own resources to address the crisis, with [...] China largely playing on the financial sidelines. ${ }^{27}$

This is a rather typical political behaviour on of the part of China insofar far as harsh world problems are concerned; that is, being engaged more rhetorically than practically and limiting costs as much as possible. One can observe a similar stance in climate change talks, where China does as much as possible to limit its commitments. ${ }^{28}$

The cash-strapped governments of Southern Europe also strive for Chinese investments on the real estate market. The sovereign-debt crisis in Europe has also meant a depreciation of the euro; the currency fell about $17 \%$ against China's RMB from the beginning of 2010 to the end of July 2013. This made real estate

${ }_{25}$ D. Pierson, H. Chu, China Moves to Prop Up Europe's Economy, "Los Angeles Times", 15.01.2011.

${ }^{26}$ L. Wei, A. Browne, A. Latour, China CIC Chief Sees Rising Risk of Euro Breakup, „The Wall Street Journal", June 7, 2012.

${ }_{27}$ J. Kirkegaard, Why the euro zone crisis will impact little on Europe's relations with China, "East Asia Forum", April 3, 2012.

${ }^{28}$ K. Ritter, U.N. climate talks impasse ends as China and India drop demands, "Washington Post", November 24, 2013. See also: Analysis of Climate Policies of China, The United States and The European Union, Social Science Academic Press 2010. 
in Europe more affordable for Chinese buyers, and many countries tried to attract them to invest in properties. One of the most spectacular incentives is the offering of visas for those who purchase prime properties. Greece and Cyprus offer fast-track permit processes for purchases of at least 250,000 euros and 300,000 euros, respectively. In Portugal, the program has a minimum price of 500,000 euros, which still far less than the minimum 1 million pounds that Great Britain demands. ${ }^{29}$ Keeping in mind that a 200 -square-meter villa in Spain costs the same as a 68-square-meter apartment in central Shanghai, one can expect that the number of Chinese homeowners in Europe will grow. In 2012 the small state of Cyprus alone attracted more than 1,000 Chinese citizens, so Spain or Portugal (much bigger countries offering access to the Schengen zone) should be able to attract thousands. ${ }^{30}$

Wealthy Chinese are also attracted by other countries. For example, Hungary offers five-year residency visas for investing 250,000 EUR in a special government bond programme. In late 2013, Malta outbid everyone by offering full EU citizenship for 650,000 EUR, which sparked security concerns among other member states. ${ }^{31}$

Chinese investments in Europe have been growing rapidly since the beginning of the financial crisis. This was caused by a combination of factors - lower prices in Europe, the rising purchasing power of China and an array of incentives aimed at attracting foreign investors. Despite growing concerns among EU member states over the rising Chinese presence in Europe, there is no evidence that it threatens security in any way. Chinese investments activities are still limited in number and value and have a rather positive influence (if any at all) on the European economy and markets. Nevertheless, they should be monitored and each major transaction should be examined for its impact on European security interests.

\section{Chinese lobby in the Council?}

However much one can debate over the size of Chinese investments in practice, the fact is that European politicians endeavour to obtain them, thus giving Beijing the chance to use them as a political tool. A good example of this is the visit made by Klaus Regling to the PRC in October 2011. Regling was Head of the European Financial Stability Facility (EFSF), a special fund set up to rescue endangered euro-zone states. He travelled to China for the sole purpose

${ }^{29}$ H. Almeida, Needy EU Nations Woo Chinese Home Buyers to Ease Slump, "Bloomberg. com”, August 22, 2013.

${ }^{30}$ J. Chow, Cash-Strapped Nations Race to Attract Chinese Immigrants, "The Wall Street Journal", July 30, 2013.

${ }^{31}$ H. Warrell, C. O'Murchu, 'Passport for sale' plan raises concern among EU members, "Financial Times", December 9, 2013 
of asking for China's financial engagement in the Fund. According to Chinese officials, they imposed some political conditions, e.g. that the EU should first stop insisting on RMB depreciation, and only then could they count on Chinese financial support. ${ }^{32}$

Chinese "bond diplomacy" is another example of it trying to use new economic power as a foreign policy instrument during a financial crisis. Chinese leaders visited indebted countries such as Spain, Greece and Portugal, making promises along the way. Although it is not clear how many of them have materialized into investments, they certainly did win political support. Godement and Parello-Plesner believe that southern European countries were against putting pressure on China when the Germans and the British demanded reciprocity in access to the public procurement market. ${ }^{33}$ Beijing could have promised financial support in return for political support in the EU institutions.

It is worth noting, however, that such behaviour did not differ much from the Chinese policy before the crisis. China has always tried to influence the European decision making process, exploiting differences between member states. It traditionally combines economics with politics when negotiating big contracts with European counterparts, for example the Airbus plane acquisition or the Maglev train.

A few years ago access to the Chinese market was the only precious card they could play. Now the Chinese foreign policy "toolbox" has increased and become enriched by their ability to use investment promises. Such promises are not only used as an argument in horse-trading negotiations, but also as an element of public diplomacy. ${ }^{34}$

There is no evidence that China has managed to build a permanent "lobby" in the EU, using countries that are dependent on Beijing in one way or another. China finds different allies in Europe on a case-by-case basis. Surprisingly, in the recent conflict over solar-panel exports it was the German government that was the biggest critic of confronting China on this issue. Berlin did not want to jeopardize its economic relations with China for the sake of a few solar-panel producers, even though many of them were German. ${ }^{35}$ Germany, which together with France has been usually perceived as an advocate of a strong common European bargaining position with China in order to protect its companies, ${ }^{36}$ played the role of the deal-seeker in this conflict.

${ }^{32}$ China May Impose Conditions for Helping Euro Zone, "Spiegel Online”, October 28, 2011.

${ }_{33}$ F. Godement, J. Parello-Plesner, Wyścig...

${ }^{34}$ Ibidem, p. 16.

${ }^{35}$ M. Dalton Solar-Panel Dispute Burns Hole in EU Strategy, "Wall Street Journal", August 20, 2013.

${ }^{36}$ F. Godement, J. Parello-Plesner, Wyścig... 


\section{Final remarks}

Since the beginning of the financial crisis relations between the EU and China have fundamentally changed. Beijing used to be a recipient of European aid and investments. Nowadays, China is perceived as a donor and investor, and thus the status quo has changed. Coming back to Whalley's ${ }^{37}$ concept of economic power, Chinese "bargaining power in cooperative arrangements between countries" has definitely increased, and so has its retaliatory power. Beijing has a new instrument that can be used in political relations with European partners: investment promises. For the time being its importance may be limited, but it could become very valuable for China in the future.

There is no evidence that Chinese economic activities pose a danger to European interests in these times of the economic crisis - their scale is small and their influence could be local at the most. However, taking into account the rapid growth observed in recent years, this situation is more than likely going to change. Although China might be rather reluctant to seek coercive ways of dealing with the EU, it is clearly focused on promotion of its national interests. Due to this fact member states and the EU itself should monitor Chinese economic activities, keeping in mind that they could be politically driven. In particular, Chinese stateowned enterprises and sovereign wealth funds should be closely observed, if only due to the fact that in other parts of the world they are widely used for political purposes.

\footnotetext{
${ }^{37}$ J. Whalley, Shifting Economic...
} 